\title{
Facilitating informal spaces and discussions in the online environment (not always) about assessments
}

\author{
Matthew Mesley \\ University of Plymouth, UK
}

Keywords: online environment; informal learning; assessments; learning spaces; Covid19.

\section{The challenge}

During 2021/21, online delivery and support became the norm for Learning Development practitioners. For some students the online environment in Zoom or Teams was the primary directed learning space in which subject content and development support was delivered. This has resulted in students having fewer opportunities to take advantage of peer-to-peer discussions, or to meet and interact collaboratively in informal learning spaces - spaces that students increasingly tend to find vital to their learning (Beckers et al., 2015). Traditionally, informal learning spaces can describe specifically designed areas, such as those found in university libraries, learning centres, or computer rooms, social spaces, or cafes. They can also include the learning which might take place in ad hoc spaces, such as the corridors before or after a seminar and in-between breaks. Within these definitions, informal learning is often limited to 'student learning outside of designated class time' (Matthews, Andrews and Adams, 2011, p.107). However, definitions of formal and informal learning spaces have often been contested, and with the shift from teaching in a physical context to an online environment, the line between these spaces is increasingly blurred (Colley et al., 2003). Clearly informal learning spaces can act as a bridge or as a transition to and from formal learning and comprise a continuum of different learning experiences ranging from informal to formal (Sefton-Green, 2004; Eurat, 2010). As the last year has demonstrated, they can also extend to informal activities online, such as planned breakout sessions or informal conversations and chat. 
With this in mind, I wanted to see how these informal or non-formal spaces could be structured (or be encouraged to develop organically) in an online learning environment, and how they might be facilitated. As a Learning Developer who teaches academic writing - a subject that students are often apprehensive about - I wanted to explore how to carve out informal learning opportunities so that students could ask questions, express the difficulties they face, and articulate any anxieties they have regarding forthcoming assessments. Indeed, at a time when many students' mental health is suffering (Norton, 2021), I wanted to create a space where they could express their thoughts and feelings about their assessments, and hopefully also share tips and suggestions between themselves. In other words, I wanted to encourage discussions which became part of the problem-solving process in which students work out what they need to do for a particular assessment, or how to go about a specific task. I recognise that such informal learning spaces are not a panacea, and that there might be a tendency to romanticise them (Berman, 2020). However, informal online spaces can enrich the overall learning experience, and act as a buffer against formal online environments such as learning management systems, providing students with new ways to share ideas, collaborate, and learn (Czerkawski, 2016).

\section{The response}

My main solution for incorporating informal spaces was to begin the majority of my sessions with an exercise using the Breakout room feature on Zoom, in which students were asked to talk about their forthcoming assignment. Sometimes I would ask specific questions, such as what problems or challenges they might foresee with a particular assignment, or what had they found useful in the past in tackling previous assignments. The rationale was: (i) to allow them an opportunity to talk to their peers; (ii) to test - without my presence intruding - for themselves their understanding of what they needed to do with an assignment; and (iii), begin, if they had not already begun, to view their assignment as a process which would need to be broken down into parts. This exercise sought to recapture the informal learning spaces or moments pre-Covid-19, while at the same time guiding the conversation towards the Learning Developer's pedagogic 'bread and butter': a more rounded understanding of their assignment. 
As I 'jumped' into breakout rooms, I noticed that conversations sometimes took a different direction than was planned. For instance, groups of students might focus on a particular question over another; or the question may have shifted, or a different discussion about their assessment begun. For example, if the assessment instructions were viewed as unclear, students discussed what they thought the assessment was actually asking of them, rather than considering what challenges they might face. In so doing, I reflected that students appeared to be reassured by these conversations; a collective understanding of an assignment was formed which then successfully anchored the broader session - this was frequently on academic writing, using evidence, or critical analysis - to the students' own understanding of the assessment instructions and criteria. Furthermore, I noticed that students appeared to appreciate that I had - to use one student's expression - 'allowed' discussion of the assignment. There was clearly a recognition that this kind of space, in which students could ask questions or articulate any uncertainties between themselves, were few and far between, particularly if lecturers expected the process of understanding to take place outside of the formal online environment (Magyar, McAvoy and Forstner, 2011).

\section{Recommendations}

Even though my response was initially more intuitive than planned, the positive response from students highlighted the need for this kind of space. It also benefited me, particularly with cohorts I was unfamiliar with, as it gave me a snapshot of current anxieties and a guide to their comprehension of future assessments. In other words, it offered a lens into how students thought about, and would start to tackle, their assignments. In a couple of sessions, the identification of any obstacles or barriers they would face was in fact integral to their assessment; thus, the space both allowed for the articulation of their concerns and clarified how the problems they faced needed to be incorporated or reflected upon within their assessment.

Further, the online environment highlighted how essential this kind of space was, and that potentially this had been overlooked in the rush to move learning online. Personally, I may also have taken these spaces for granted in my previous teaching. As such, my main recommendation would be that we reflect, collectively and individually, on how we might 
be able to incorporate and harness this kind of space in face-to-face sessions, or indeed what might work best by being kept online. As suggested, this kind of space likely already occurs within face-to-face environments, but could be enhanced and acknowledged further. Other questions are worth considering too. How do we plan for these spaces in our sessions? Is the very potential rooted in offering up the time and space, rather than incorporating this formally into our work? I would argue that it is useful to guide or facilitate this space, while at the same time being willing to adapt. Moving forward, I would also suggest thinking about how we can best evaluate these spaces. Finally, might more be said about the value of this type of learning in comparison to the delivery of formal learning, and how can the wider Learning Developer community benefit from this type of approach?

\section{References}

Beckers, R., Van der Voordt, T. J. M. and Dewulf, G. (2015) 'A conceptual framework to identify spatial implications of new ways of learning in higher education', Facilities, 33(1/2), pp.2-19. https://doi.org/10.1108/F-02-2013-0013.

Berman, N. (2020) 'A critical examination of informal learning spaces', Higher Education Research \& Development, 39(1), pp.127-140. https://doi.org/10.1080/07294360.2019.1670147.

Colley, H., Hodkinson, P. and Malcom, J. (2003) Informality and formality in learning: a report for the Learning and Skills Research Centre. Learning and Skills Research Centre 2003. Available at: https://core.ac.uk/reader/91282?fbclid=IwAR0LORL7II86iGV94Dpp-gtiFxV_QPThXQ4Qn4Y_UrryfznNT81vYYYmBY (Accessed: 9 June 2021).

Czerkawski, B. C. (2016) 'Blending formal and informal learning networks for online learning', International Review of Research in Open and Distributed Learning, 17(3), pp.138-156. Available at: https://files.eric.ed.gov/fulltext/EJ1102701.pdf (Accessed: 10 June 2021). 
Eurat, M. (2004) 'Informal learning in the workplace', Studies in Continuing Education, 26(2), pp.247-273. https://doi.org/10.1080/158037042000225245.

Magyar, A., McAvoy, D. and Forstner, K. (2011) "'If only we knew what they wanted": bridging the gap between student uncertainty and lecturers' expectations', Journal of Learning Development in Higher Education, Issue 3, March, pp.1-18. https://doi.org/10.47408/jldhe.v0i3.68.

Matthews, K. E., Andrews, V. and Adams, P. (2011) 'Social learning spaces and student engagement', Higher Education Research \& Development, 30(2), pp.105-120. doi: https://doi.org/10.1080/07294360.2010.512629.

Norton, A. (2021) 'Making student mental health a priority'. Available at: https://www.officeforstudents.org.uk/news-blog-and-events/blog/making-studentmental-health-a-priority/ (Accessed: 5 June 2021).

Sefton-Green, J. (2004) Literature review in informal learning with technology outside school, FutureLab series 2004.7. Available at: http://eprints.Ise.ac.uk/id/eprint/41609 (Accessed: 11 June 2021).

\section{Author details}

Matthew Mesley is a Learning Development Advisor at the University of Plymouth and currently works with students from the Faculty of Health. In a former life he was a medieval historian, and has written on medieval miracles, sex and gender, Jewish-Christian relations, and the Crusades. He has an MPhil from the University of Cambridge, a Ph.D. from the University of Exeter, and is a Fellow of Advance HE. 